\title{
Radicalism in Bogor as Urban Area
}

\author{
Muhamad Syauqillah ${ }^{1}$, Imam Khomaeni Hayatullah ${ }^{2}$ \\ \{muhamadsyauqillah@ui.ac.id ${ }^{1}$, imam.hayat14@gmail.com $\left.{ }^{2}\right\}$ \\ ${ }^{1,2}$ Terrorism Studies, School of Strategic And Global Studies, Universitas Indonesia
}

\begin{abstract}
Bogor became an important buffer zone of Jakarta in the terrorist acts that took place in Jakarta. More than 20 acts of terrorism have settled in Bogor for the past decade. This research will analyze radicalism in Bogor by using qualitative method with literature study and interview. The social and collective action of Charles Tilly became the theory underlying this study. The conclusion of this research is that Bogor area is strategic area for radical network in Jakarta, Depok, Tangerang, Bekasi and Bandung. There are different factors that led to Bogor being an alternative to radical networks in Indonesia.
\end{abstract}

Keywords: radicalism, terror, social, collective action, Bogor

\section{Background}

Bogor is a buffer zone of the capital city of Jakarta, evidenced by the large number of workers who choose to live in Bogor and work in Jakarta. As proof, the number of commuter line passengers from Bogor based on PT KAI Jabodetabek Commuter data, KRL users throughout 2016 increased $8.95 \%$ to 280.59 million passengers from 257.53 million passengers. Of these, Bogor lane users reached 190.83 million passengers or reached 68 percent of the total Commuter Train passengers in 2016 (The Central Statistic Agency https://www.bps.go.id/publication/2017/11/27/500b5f875d5762ffb4e7a589/statistik-

transportasi-darat-2016.html.) The population of Bogor City based on the Central Statistics Agency data in 2016 totaled 1,064,687 people (Badan Pusat Statistik Kota Bogor,https://bogorkota.bps.go.id/statictable/2018/05/14/117/banyaknya-penduduk-menurutkelompok-umur-dan-jenis-kelamin-2016.html) and Bogor regency totaling 5,715,009 people (Badan Pusat Statistik Kab Bogor, https://bogorkab.bps.go.id/statictable/2017/05/18/9/jumlahpenduduk-kabupaten-bogor-menurut-kecamatan-.html).

Bogor's name according to history comes from the word "Buitenzorg" the official name of the Dutch Colonialists. Another opinion revealed that Bogor originated from the word "Bahai" which means Cow, which happened to be a statue of a cow in the Bogor Botanical Garden. While the next opinion states, Bogor comes from the word "Bokor" which means palm tree stump (kawung). Another version mentions the name Bogor has appeared in a document dated April 7, 1952, written "Hoofd Van de Negorij Bogor" which is more or less meaning the Head of the Bogor Village, which according to information later that Kampung Bogor is located in the location of the Bogor Botanical Garden which was built in in 1817. The origin of the existence of the Bogor Regency community, its origin was from the merger of nine Settlement Groups by Governor General Baron Van Inhof in 1745, so that it became a community unity that developed into a large time later. This community unity is the core of the Bogor Regency community. 
The Central Government of Bogor was originally still in the Bogor City region which is precisely in Panaragan, then based on Government Regulation Number 6 of 1982, the Capital City of Bogor Regency was moved and set up in Cibinong. Since 1990 the center of government activity has occupied the Government Office in Cibinong (http://bogorkab.go.id/index.php/page/detail/1/sejarah-kabupaten-bogor\#.W6_d12gzY2w). At the beginning of the 5th century AD, the center of the Kingdom of Tarumanegara had developed with its king Purnawarman and included the initial kingdom in the archipelago. This is based on written sources written by the Chinese writer Fa-Hsien. A Chinese priest who in 414 AD stopped by an area that was estimated to be the Kingdom of Tarumanegara.

Evidence that shows the existence of the Tarumanegara Kingdom is an inscription. The inscriptions include the Ciaruteun inscription which is now located in Ciampea Bogor, the Sand Koleangkak Inscription in the West part of the City of Bogor, and the Inscription Kebon Kopi in the village of Muara Hilir, Cibungbulang, Bogor. In addition to these inscriptions which are now included in the Bogor Regency, there are also Tugu Inscriptions which mention the existence of the Tarumanegara Kingdom which is now located in Jakarta (Fadilla, 2012: 20).

Before Islam entering, Bogor is a region of Hindu Budhist. The spread of Islam to Bogor cannot be separated from the spread of Islam in the Sunda lands in general. As is also the case in most of the archipelago, Islam spreads on Sundanese land using the mechanisms of trade, politics and marriage. The spread of Islam is peaceful (Nina Lubis, 2011: 29). Not only Islamic traditions such as da'wah, but spiritually, Sufism supporting the spread of Islam in Sundanese Tatar, including Bogor (Nina Lubis, 2011).

$\mathrm{n}$ the development of the acceleration of Islamization in Sunda land was carried out by educational institutions, namely Islamic boarding schools. Recorded for the Bogor area, there are several Islamic boarding schools which play an important role, including; Bakom Islamic Boarding School (1883) and Al-Falak Islamic Boarding School (1907). After independence, several Islamic boarding schools appeared, Nurul Hidayah Islamic Boarding School, Tarbiyatunnisa Islamic Boarding School, Nurul Iman Islamic Boarding School, Hidayatul Athfal Islamic Boarding School, Al-Fuad Islamic School. In addition, the role of Islamic da'wah was also carried out by Arab descendants in Empang Bogor, the pioneers of the Arab community in Empang was Habib Abdullah bin Muhsin Al Attas, of the Yemeni Hadramaut, came to Empang in 1895. The point of spread of Islam spread by Habib Abdullah was Islamic teachings about the manners and unity of the people, plus Islamic teaching to ordinary people in the Empang region (Nurhayati, 2016: 2-3)

The historical development of Islam in Bogor did not rule out the growth of other religions, such as Christianity, Catholicism, Hinduism, Buddhism. There are also traditional religions adopted by residents of the city of Bogor such as Sunda Wiwitan. Therefore, in terms of the historical aspects of religion in Bogor, Indonesian Islamic culture is very attached because indeed the entry of Islam into Bogor, as well as other regions in the archipelago, acculturated local culture with Islam. And the diversity of Bogor's population based on ethnicity and religion is a reality that has been for centuries. However, historical geneology, Islam in Bogor experienced a significant shift. The shift started from the terms of the Indonesian Islamic state. The Bogor area is a network of Indonesian Islamic States in the Pasundan region. For the movement of the Islamic state of Indonesia, Bogor is one of the buffer zones of the center of the movement in Garut, hence the genealogy of the radical movement in the city of Bogor has strong roots. And as the development progresses, NII has undergone a transformation from Al Qaeda, Jamaah Islamiyah to becoming ISIS today.

Bogor became the spotlight during the arrest of Umar al Faruq in 2002. Umar Faruq's interaction with Bogor occurred when Hezbollah facilitated Umar's escape from Malaysia due 
to immigration problems. While in Bogor, Umar was introduced to Hezbollah by Haris Fadilah alias Abu Zeid alias Abu Dzar (figure of NII in Bogor), Umar also married the son of Abu Dzar, Agustina (Said Ali, 2014: 280). Not only Faruq, who has a relationship with the Bogor NII Network, Heri Golun, the Kuningan suicide bomber, was transformed into a radical figure when he joined the NII Bogor while working as a glass factory worker (Gatra, 2009) In addition to Heri, there are still a number of terrorism offenders who have strong relations with the Bogor network. The dynamics of the Syrian conflict and the ISIS Declaration ${ }^{1}$ by Abu Bakar Al Baghdadi brought Bogor to become one of the locations of the ISIS declaration in Indonesia, and now Bogor has become so important in the radicalism movement after Abu Bakar Baasyir ${ }^{2}$ known as "icon refresentative" radical group, transferred from the Nusa Kambangan Penitentiary to Gunung Sindur Prison. After ABB's move, the radicalism narrative in Bogor became stronger, the article, Juhanda, a former convict in the case of architects and bomb book terrorists in 2011, was involved in the attack on the Oikumene churches of Samarinda and Sunakim, the Terrorists of Thamrin, living in Bogor.

Strengthening radicalism in Bogor is evidenced by the fact that there is ISIS military training. The Rajaratnam School of International Studies report stated that on 15 October 2015, 71 ISIS supporters conducted military training in the Bogor area (Taufiqurrahman, 2015: 13). The selection of Bogor as one of the areas of military training by radical groups is not only carried out by ISIS. Historically, the Ambon conflict has made Bogor one of the military training areas of Laskar Jihad. The training was carried out with Afghan, Moro and Kashmir alumni instructors and student regiment alumni (Hasan, 2005).

The selection of Bogor as one of the important areas for radical movements is due to logistical arguments and access. Military training can be held because nature in Bogor is very supportive, ISIS supporters do not need to be busy with logistics, because everything is available in nature. Likewise for those who live in Bogor, by planting ISIS supporters can survive (Anonymous, 2017). In addition to logistical arguments and access, the election of Bogor was also supported by the social fact that the support of the Bogor community for the idea of Caliphate (khilafah) was quite large. The Equal Institute's research findings titled The Faces of Islamic Defenders said that around 46 percent of residents stated their agreement with the idea of the Caliphate (Hasani, 2011: 95). Another study said that one of the reasons why Bogor became a fertile ground for radicalism was the existence of Hizb ut-Tahrir with the ideology of the Caliphate in the environment around the Bogor Agricultural Institute campus and IPB was unique as the center of HTI's movement to various campuses in Indonesia (Collin, 2004: 9).

Another fact that makes Bogor a fertile habitat for radical movements is the level of intolerance is quite high. The situation seems linear with intolerance events involving radical groups in Bogor, such as data compiled from the Setara Institute which calls Bogor as one of the intolerant regions in West Java.

Not to mention factually Bogor has become one of the strategic cities for Salafis, both Jihadi and Murni (in the next section will be explained about Salafi). The study of the Salafi movement in Bogor calls the Salafi Bogor as a religious movement systemically has a network with salafi

\footnotetext{
${ }^{1}$ Several studies on radicalism movements in Indonesia have found the fact that transformations have taken place in the body of radical movement, these transformations are somehow influenced by international geopolitical situations. The contact of radical movements with transnational groups is the dominant factor that can be used as an answer to these changes. But before the ISIS phenomenon was rife in the world, radical movements were still in the classical pattern, such as the method of struggle; doctrination, recruitment and campaigns, are still not as advanced as they are today.

${ }_{2}^{2}$ Abu Bakar Baasyir has pledged allegiance to ISIS, acknowledged by one of the former terrorist prisoners, even though the news about ABB's pledge contained a cross of opinion among his supporters. The personal interviews of former terrorist prisoners in June 2017
} 
in other regions in Indonesia (Suhanah, 2010: 102). The ISIS declaration, the declaration of the HTI caliphate, the involvement of several terrorist prisoners who settled in Bogor, the development of the Salafi Jihadi became the assumption that Bogor was in the phase of developing radicalization and the process of changing the status of the transit area became an incubator area of radicalism movements in the outskirts of Jakarta.

This research was carried out to obtain a portrait of radicalism in Bogor related to actors, ideology and the spread of radical understanding.

\section{Research Method}

This research was carried out with the Bogor City and Bogor Regency research areas. Data collection was carried out by documenting various studies on terrorism, radicalism that led to terrorism, reviewing several studies on terrorism and several studies that have been conducted relating to Bogor and in-depth interviews with informants who were considered competent with the research theme.

\section{Literature Review}

The British Parliament (House of Common, 2012) through the Prevention Strategy Act (Prevent Strategy) which they have validated, has definitions around terrorism, radicalization, extremism and violent extremism, as follows:

1) Terrorism is "the use of threatening actions ... designed to influence government or intimidate the public or parts of the public ... with the aim of achieving political, religious and ideological ideals".

2) Radicalization is "the process by which a person provides support for acts of terrorism and other forms of extremism that lead to terrorism".

3) Extremism is an "active or vocal action that shows an attitude contrary to British values including democracy, rule of law, individual freedom and tolerance between religious communities and beliefs."

4) Violence Extremism is actions that provide support for acts of violence to achieve extreme targets.

The definition above at least provides an overview of how the state describes acts of violence based on qualifications of action. The emergence of radicalism trends that lead to acts of terrorim are the main reason behind the emergence of the above terminology.

Wiktorowicz outlined the results of ethnographic research conducted in London in 2002 with a focus on the Al Muhajiroun group, a radical Islamic group founded by Omar Bakri Muhammad. The research conducted by Wiktorowich is directed to answer questions about why thousands of British teenagers are attracted by radical Islamic movements based in the UK such as Hizbut-Tahrir, Supporters of the Shariah, Al Muhajiroon and Al Qaeda. It seems like Sageman, he has the same opinion about the influence of social networks on the formation of radical behavior, but he also explained that one of the important factors that cause radical action is due to psychological crisis. However, the weak point of this research is not being able to negate the fact that the followers of Al Muhajiroun are radical groups in terms of interpreting religious teachings but do not automatically engage in acts of terrorism, they generally have radical views but do not have a track record as terrorists. This research is very useful in terms 
of explaining the influence of social psychology which has a significant impact in influencing the actions of adherents of radical Islam such as the research that he has done (Quintan Wiktorowicz, 2005).

In A Decade Lost, Rethinking Radicalisation and Extremism, Arun Kundari tried to present a new narrative about the definition of radicalism and extremism that tends to lead to acts of terrorism. In this research, Kundari explained that previous research was considered to be a legitimacy for governments in various countries to create policies for the war on terror. According to him, the government tends to agree with the narrative of the research presented by previous researchers who ignored the essential factors behind every terror incident and the reason the terrorists carried out their actions. He gave an example related to "speeches by extremists" as the main factor of acts of terror as a weak assumption because the speeches expressed by extremists were not the dominant factor why terrorists acted. Kundari generally underlines the obedience on substantial factor behind every single cases, become the reason why the government in every country failed to solve the problem of terrorism and precisely ignoring the basic rights of citizen (Arun Kundari, 2015). Although this research does not fully demonstrate qualifications as an anti-thesis for previous research, the position of this research is fair enough to place previous research including placing civil rights as a priority in creating anti-terror policies. Kundari's statement clearly shows that there must be essential basic clarity of terrorism legislation so as not to be misdirected.

Research trends in the global sphere have a strong relationship with the development of radicalism and terrorism in Indonesia, at least after the emergence of ISIS which has sympathizers in Indonesia. There is a signal that is marked by the terror incident in Thamrin and the attack on the officers in Solo by terrorist groups is a sign that the ISIS threat is very real. However, there has not been much academic research that details in detail what actually happens during every terror attack that uses ISIS' emblems. How do extremist groups in Indonesia build relationships with ISIS' networks. What is the public response to extremist groups. Seeing this phenomenon, several researches have tried to explain the social phenomena that currently occur in Indonesia. The Saiful Mujani Research and Consulting (SMRC) survey in June 2017 mentions that one in 10 Indonesians wants the Khilafah as a substitute for the Unitary Republic of Indonesia. On the other hand, as many as 2.7 percent of respondents agreed to the existence of ISIS (SMRC, 2017). Different to LSI and SMRC, Setara Institute in 2015 and 2016 conducted a survey of views that explained the phenomenon of the views of the younger generation in Jakarta and Bandung, indicating that the younger generation sought religious information from the internet (Setara Institute, 2016) and moreover, there is 1 in 14 high school students agree with the existence of ISIS (Setara Institute, 2015). So that it can be said, the threat of radicalism is real.

Then what ideology is often referred to as the root of the radical movement in the world. There are several studies explaining the current world social phenomena, the European Union Parliament study in detail explains the salafi relations with radical movements, the study states the support of the Salafi movement in relation to armed violence in various countries such as Indonesia, Philippines, Syria, Morocco, Libya, Tunisia , Egypt (European Union Parliament, 2013). The SETA Foundation, one of the research institutions in Istanbul, does the same thing with the European Union which examines the relationship of the movement and acts of terrorism in Europe. Al Qaeda Strike Back, which said that since 2007, more than 4500 internet sites supported by radicalization and jihad and monolithic religious understanding (Kardas, Ozdemir: 2015).

To give an overview of salafi, Noorhaidi Hasan conducted a study of the salafi movement, namely about Laskar Jihad. Noorhaidi called this group's relation to the Ambon and Maluku 
conflicts while historically reviewing the salafi movement in Indonesia. Noorhaidi also revealing the salafi transformation as the missionary movement turned into a militant group. Noorhaidi also called Salafi Jihadi a form of transformation (Hasan, 2005).

John A. Turner explicitly stated that Salafi Jihadi as a religious-political ideology based on the concept of Islamic fundamentalism, Al Qaeda as a form of salafi organization. Turner said there are four main points of Al Qaeda's teachings; Salafism, Jihad, Jahiliyah and Hijrah (Turner, 2014). These four conceptions are very relevant in relation to the Indonesian militant doctrine (Foreign Fighters Terrorist) which goes to Syria, on the grounds of hijrah and jihad. Turner's approach to Salafi seems to be different from Frazer Egerton in his book Jihad in The West: The Rise of Militant Salafism, Frazer conducts studies of individual individuals who have involvement in terror attacks in various cities in the world, such as Paris, London, Madrid, and other cities. in this world. Frazer unraveled his findings which stated that the perpetrators before committing terror turned out to have a salafi jihadi doctrine. Frazer pointed out the case of the 2001 American attack, some of the perpetrators who then carried out terror attacks came to the Quds Mosque in the city of Hamburg, this mosque became the destination of people from Arabia and various parts of the world. This mosque found a message that did not compromise such as the message of the invitation to fight infidels, Jews and Israel (Egerton, 2011).

The current salafi phenomenon is also observed by Henri Lauziere as stated in the book The Making of Salafism: Islamic Reform in the Twentieth Century. In his book Henri saw the historical roots and salafi doctrine rooted in the thoughts of Ibn Taymiyah and Ahmad Ibn Hambal, in the 20th century Henri called the name Muhammad Rasyid Ridho as one of the influential salafi figures in the modern salafi movement. Henri also mentioned that there are two major conceptions in salafi. At the end of his book Henri, there are two major concepts of salafi, Puritan Salafi and Modern Salafi (Lauziere, 2016), The fundamental difference between the two types of salafi is the ability to change by the times.

1) To facilitate this research, researchers tried to formulate a salafi typology formulation that has a radical tendency. Some approaches that can be used, include:

2) To use the Takfiri ideology to the groups with the different viewpoint;

3) To call Pancasila and 1945 Acts as the infidel system;

4) Indonesia is an infidel country, and its government is an Asharut Thagut (the thogut army);

5) To proscribe respecting state's flag; to burn the flag;

6) To allow the violence as a strategy to reach the goal;

7) To allow robbing because Indonesia as a Darul Harb (a war zone);

8) To allow not praying Jumat by the reason that the Calipathe (Khilafah) is not yet established;

For ease of explanation of the relation of salafi-jihadi group with the spread of radicalism in Bogor, the use the approach of Charles Tilly. Tilly is an expert on the phenomenon of social movements. The researchers includes the activities of these radicalists as social movements. This radicalism movement in Bogor is not singularly carried out by one group. Because the nature of the spread of radicalism in Bogor is carried out by sharing community groups. There are groups that only spread radical religious ideas at the stage of considering other groups to offer heresy. There are also radical groups that deny or mislead others. There are radical groups, who even want to change the form of Indonesia. However, these groups have the same concept of religious equality. They consider other people outside their group to not understand Islam well, they refuse to do dialectics with other groups, other groups are considered to have little religious knowledge. 
Back to tilly, he revealed what was a social movement, for him;

\begin{abstract}
"a sustained series of interactions between power holders and persons successfully claiming to speak on behalf of constituency lacking formal representation, in the course of which persons make public visible demands for changes in the distribution or exercise of power, and back those demands with public demonstrations of support "(Tilly, 1999).
\end{abstract}

In general, Tilly holds that social movements are organized, sustained, rejects selfconscious and shared identities among those involved. In his argument, besides focusing on the organization as a social movement, Tilly also connects social movements that lead to a broader "political process", which is being used for various activities by building access to build more established government (established government). Referring to Tilly's intentions, people who are close to the Salafi teachings finally form a group, because there is a shared identity between them. In Bogor they transform by doing activities in the public. Conduct studies at mosques, such as studying mosques on campus, mosques in offices. in addition to operating in the mosque, then salafi group is also building schools (pesantren). Bogor later became the basis for the spread of radicalism. This group in Bogor is clearly well organized. The social movements of the salafi group resulted in new currents in the Islamic style in Bogor. This social movement also finally formed a new ashbiyyah in terms of Ibn khaldun. Aside from ashabiyyah, it can be referred to as identiy fusion

Identity fusion is a feeling of unity with a group that invites someone to bind their feelings into groups (Swann, et al. 2009)., The suicide bombers are in a group, which is each group has its own values and goals that are shared with its members. When the identity of the terrorist group members who carry out these suicide bombings melt into the group or experience identity fusion, then they will make special sacrifices, such as being suicide bombers in the interests of their group, while they do not care that their actions is wrong action in religious and social norms.

The statement that suicide bombing behavior is caused by a psychological process called identity fusion is reinforced by experimental research evidence conducted by Swann, Gomez, Seyle, Morales, \& Huici (2009) from Oxford University, led by Professor Harvey Whitehouse. This process is believed to be the main drive that makes people willing to become suicide bombers. In fact, being able to encourage someone to sacrifice his life is much stronger than just identifying himself in a group. The process of identity fusion is a deep feeling that blends in a group because it is forged by a feeling of one feeling. They form a relationship of psychological brotherhood like biological relatives of the same environment and experience so that the desire to defend and protect each other arises.

so that martyrdom and martyrdom are noble things because of the group's desire

This research is also based on interviews conducted by the researchers of several people from friends of former terrorism prisoners. Interviews were conducted to obtain information findings from former Napiter. The findings obtained mention the experience related to terror activities carried out in the Bogor area. In addition, information was also obtained regarding experience and regret after joining terrorist groups. In addition, interviews were also conducted with various parties related to the Bogor Region and radicalism. 


\section{Discussion}

The status of Bogor as a supporting satellite city of the Capital City of Jakarta is one that needs to be highlighted. As many as half a million people live in Bogor towards Jakarta leave their own problems, especially in residential areas with housing typologies, with various types of housing, simple, medium and luxurious status. The reason is, in the housing area there has been widespread radicalization of mosques by a number of groups, the empty space left by Bogor residents going to Jakarta was taken over by groups that are anti-diversity. This study found that there are two mosques in the luxury housing complex in the Bogor area to be a means of incubating the idea of intolerant idea (Anonymous, Indraprasta Resident)

The situation of radicalization in the housing area in Bogor, both cities and districts, is almost inversely proportional to the situation in the settlement. The anti-Islamic tradition doctrine which is usually echoed by radical groups is confronted forcefully by religious leaders. When radicalism experiences a nursery it is quite massive from its actors, so to suppress the rapid rate of radicalism an active role is needed from the regional government. But unfortunately, from some incidents the local government seems to provide opportunities for radical groups to gain the legitimacy of the government, but in reality, this group of groups can easily access the city government, one of the proofs, the prohibition policy on Ashura and HTI declarations.

On various occasions, Bogor is often referred to as a city with a low tolerance index, but this low level is not accompanied by government budgetary political intervention. One example of the absence of budgetary political intervention is the lack of budget for the implementation of national insight programs, recorded in the 2017 fiscal year of 50 million rupiah (http://kotabogor.go.id/uploads/images/Transparansi\%20Publik/2017/LampiranPerwali/929969-KantorKesbang.pdf). The budget is so minimal for the national insight program with the many results of studies that put Bogor as a city with a relatively high level of intolerance implying that the regional leadership is impressed with national discourse.

Such a situation might occur because of the assessment of the head of the National Police for the situation in Bogor which stated that there was no radical movement in Bogor so far. However, a number of problems have occurred due to differences of opinion and did not cause physical violence. Kesbangpol position itself is in the middle. (Kesbangpol) holds a dialogue with parties who are pros and cons of a particular problem. National and Political Unity Office (Kesbangpol) involves community leaders, police officers, sub-district heads to RT heads to build dialogue between groups involved in dissent (Interview with head of kesbangpol). There is the name of the perpetrator of the terrorism act from Bogor and uses Bogor as a consolidation location before the bombers. From 1980-2017, in Indonesia there were 38 acts of terror, of which there were at least 18 cases, where the perpetrators had lived/stopped and had relations with the Bogor network.

Table 1. 18 acts of terror had relations with the Bogor network

\begin{tabular}{|c|c|c|c|c|}
\hline No. & Perpetrators & Case & Year & Location \\
\hline 1 & Umar Faruq & Bomb Terror in Bali & 2002 & Bogor \\
\hline 2 & $\begin{array}{l}\text { Iwan Darmawan, Ahmad } \\
\text { Hasan and Friends }\end{array}$ & $\begin{array}{l}\text { Bomb Terror in Australian } \\
\text { Embassy }\end{array}$ & 2004 & Lewiliang, \\
\hline 3 & Ibrahim & Bomb Terror in Ritz Carlton & 2009 & $\begin{array}{l}\text { Bogor Network's } \\
\text { Recruitment }\end{array}$ \\
\hline
\end{tabular}




\begin{tabular}{|c|c|c|c|c|}
\hline No. & Perpetrators & Case & Year & Location \\
\hline 4 & Dani Dwi Permana & $\begin{array}{l}\text { Bomb Terror at JW Marriot } \\
\text { Hotel }\end{array}$ & 2009 & Parung, Bogor \\
\hline 5 & Syaifuddin Zuhri & $\begin{array}{l}\text { Bomb Terror at JW Marriot } \\
\text { Hotel and Ritz Carlton Hotel }\end{array}$ & 2009 & Parung, Bogor \\
\hline 6 & $\begin{array}{l}\text { The Network of Noordin } \\
\text { Top }\end{array}$ & $\begin{array}{l}\text { Warehouse Discovery } \\
\text { Explosive }\end{array}$ & 2009 & Bogor \\
\hline 7 & $\mathrm{P}, \mathrm{A}$ & Bomb Terror of Gas Pipe & 2011 & Bogor, \\
\hline 8 & $\begin{array}{l}\text { Hendi, Suhartono, Ade, } \\
\text { Guntur, Dwi }\end{array}$ & Book Bomb Terror & 2011 & GunungSindur, \\
\hline 9 & Emir, Zainudin, Usman & $\begin{array}{l}\text { Terror Plan in American } \\
\text { Embassy }\end{array}$ & 2012 & Lewiliang, Bogor \\
\hline 10 & Inisial A & Terror in Jambu Plaza & 2014 & North Bogor \\
\hline 11 & Inisial R & Issue Terror Spreader in Bogor & 2014 & South Bogor \\
\hline 12 & Nur Rohman & Bomb Terror in Polresta Solo & 2016 & $\begin{array}{l}\text { Amaliyah helped } \\
\text { by bogor Network }\end{array}$ \\
\hline 13 & Sunakim & Terror in Thamrin & 2016 & Taman Sari \\
\hline 14 & Munir Kartono & $\begin{array}{l}\text { Suicide Bombing of Nur } \\
\text { Rohman - Polresta Solo }\end{array}$ & 2016 & Gunung Putri \\
\hline 15 & $\begin{array}{l}\text { Risno, Mukhlis and } \\
\text { friends }\end{array}$ & $\begin{array}{l}\text { ISIS' member arrest at Changi } \\
\text { Airport }\end{array}$ & 2016 & Taman Sari \\
\hline 16 & Rohim & Bomb Kampung Melayu & 2017 & Taman Sari District \\
\hline 17 & Bahrumsyah & The Spread of Terror Threat & 2014 & Bogor \\
\hline
\end{tabular}

Data is obtained from some sources.

\section{The Spread of Radicalism}

The pattern of distribution of radical understanding in Bogor is in three places. These three places become fertile ground for radicalism in Bogor. These three places then become a means of mobilizing the movement and regeneration of members.

\subsection{The Mosque}

The city of Bogor according to the Regional Office of Religon Ministry, has 4931 Mosque, while the Bogor district has 8838 mosques and 6998 mosques (https://jabar.kemenag.go.id/artikel-27382). The distribution of mosques and musholla in the Bogor region is in areas of housing ${ }^{3}$, offices and settlement. On a national scale, the Ministry of Religion divided mosque typologies into several categories; First, the state mosque, which is a mosque funded by the state at the center of government. Second, the national mosque, which is the mosque proposed by the Provincial Governor to the Minister of Religion to become a National Mosque, and the financing is charged to the regional budget. Third, the Grand Mosque, which is a mosque located in the province and submitted by the provincial government to the regional office of the Ministry of Religion, is charged to the regional government. Fourth, the grand mosque, which is a mosque located in the district/ municipality and proposed by the

\footnotetext{
${ }^{3}$ This study successfully interviewed one of the housing developer workers in Bogor. The worker said that currently there is a modus operandi targeting residential mosque mosques to be used as a basis for religious movements. Even the housing developer said there was a kind of collaboration between the developers and groups who often did takfiri and heresy to other groups. Interview in Jakarta, 12 August 2017
} 
municipal government or regency to become a grand mosque, the financing of the budget is borne by the regional government. Fifth, a large mosque, which is a mosque located in the subdistrict area and submitted to KUA District to become a large mosque, the financing is charged from the local government, self-help, and others. Sixth, the Jami mosque, which is a mosque established by the community and even if there is funding from the government, the number is very limited (Dirjen Bimas Islam, 2008).

Looking at the development of the mosque in Bogor, this study divides mosques based on the area and pilgrims of the mosque. At least the mosque in Bogor can be divided into 5 types of mosques; First, the Office Mosque, this type of mosque is in an office area. This type of mosque congregation comes from office workers and factories in the Bogor area.

Second, housing mosques, this type of mosque is in a residential area, both with the type of luxury and simple housing, mosque worshipers come from residential residents who have busy working outside housing. Third, the village mosque, the type of mosque is located in the area of human settlements that live in an area for generations, this type of mosque congregation is more varied because it comes from both indigenous and immigrant residents. The four campus mosques, this type of mosque is located in the campus area, and mosque worshipers are mostly university academics. These five government mosques, this type of mosque are mosques that are established by the central and regional governments and get the operational budget from the budget. The mosque members with this type are very diverse. Seeing the development of the mosque in Bogor, the potential for emergence and the spread of radical understanding comes from mosques with the type of residential, office and campus mosques. One of the causes of this is the absence of religious authority holders and the lack of attention of residents living in the area (Dirjen Bimas Islam, 2008). This condition is increasingly alarming with the inability to enter a large moderate Islamic religious organization into residential housing in Bogor.

The domination of the mosque by radical / puritan groups turned out not only to have an effect on religious practice in the mosque area. The spread of radical understanding, however, has caused social cohesion to be disrupted, residents of housing communities who get radical doctrine have arbitrarily disseminated slander and made judgments about the practices of other community members (personal interview, 2017).

\subsection{Islamic Boarding School (Pesantren)}

Pesantren/Islamic Boarding is a non-formal institution that is characteristic of Indonesia. Since the pre-colonial period the pesantren was an educational institution that became a place to learn about science. Of course the pesantren style is closer to religious organizations in Indonesia. In general, the existence of Islamic boarding schools in this area is Islamic boarding schools with a moderate style of Islamic thought because they are affiliated to the Nahdlatul Ulama, both culturally and structurally and the Gontor Modern Cottage. However, there was an anomaly after the spread of Salafi teachings in Indonesia, as well as conditions that occurred in Bogor.

One of the phenomenal boarding school in Bogor is the Boarding School named Ibnu Mas'ud'. Many people called that Islamic boarding school Aman Abdurrahman Islamic

\footnotetext{
${ }^{4}$ This pesantren is phenomenal because Aman Abdurrahman, one of the influential figures in ISIS has been part of this pesantren. Later the desire of residents around the Islamic boarding school to close the Ibn Masud Islamic boarding school was because the accusation of the pesantren did not install the red and white flag and the burning of the red and white flag at the moment of August 17. One of the residents around Ibn Masud Islamic boarding school in Nambo village, Sukajaya said that the Ibn Masud Islamic boarding school was closed to local residents. Students who study are from outside Sukajaya, some from Solo, on August 17, a child burns banners (Red and White Flags) or orders his teacher.
} 
Boarding School (Ibrahim, 2017) one of popular figures (frontman) of Anshor Daulah's pilgrims. This pesantren is often associated with several acts of terrorism and ISIS lately, the terrorists of Sarinah Sunakim, Terror Samarinda (http://www.beritasatu.com/hukum/402111berkas-2-tersangka-bom-gereja-samarinda-siap dilimpahkan.html). Salafi Pesantren (Ibnu Mas'ud) is an example of the development of religious understandings that tend to be exclusive and closed, in contrast to most other pesantren that interact with local people. Under these conditions, pesantren can also be a place for the spread of religious radicalism.

\subsection{Hatf, The Little Foreign Terorrist Fighter from Ibnu Masud}

Hatf Saifurrasul is an Islamic boarding school student from Ibn Masud Islamic Boarding School, a 12-year-old santri was born 24 November 2003 in a village called Lamasi, Palopo, South Sulawesi. Although born in Palopo, Hatf grew up in Tawangmangu, Solo. Hatf's family was familiar with the Poso conflict and training in the Aceh jantho. Hatf's parents are one of the terrorist prisoners in Permisan Nusakambangan LP. Since kindergarten to elementary school, Hatf attended Al Irsyad Integrated Islamic Primary School, Tawangmangu, Solo. Class 5 elementary school, Hatf moved to Ibn Masud Islamic boarding school. It was at this pesantren that Hatf studied Millah Ibrahim's teachings, the meaning of kufr to thogut, Al wala Wal Baro ', jihad and mujahidin. In contrast to some Indonesian foreign fighters, who come from families that are less harmonious, Hatf is the opposite, his desire to jihad gets the blessing of his parents.

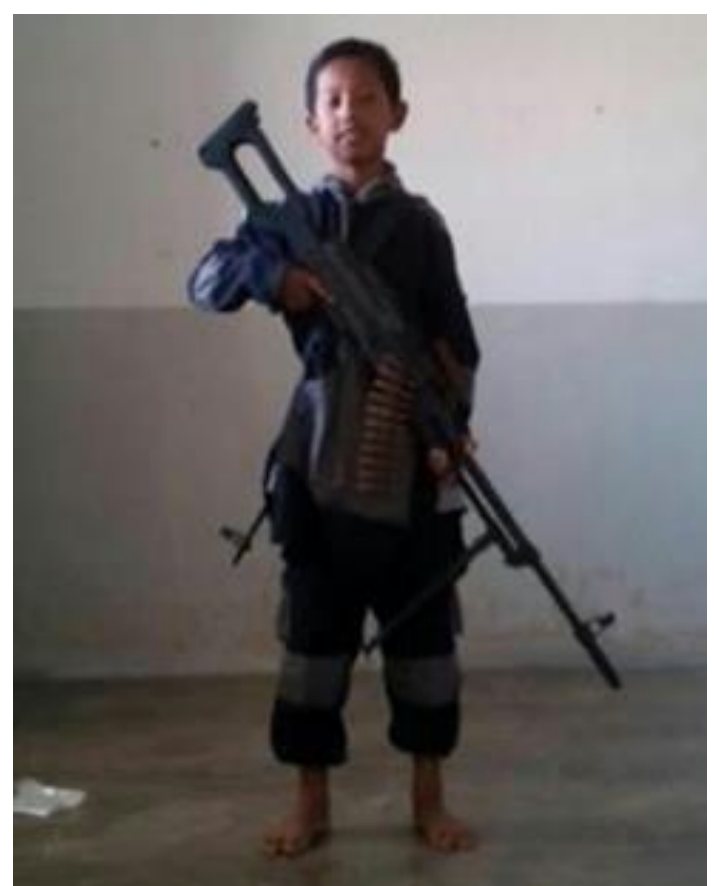

Fig. 1. Hatf Saifurrasul

Source: a letter from Hatf's parents. 
And so the role of the Salafi Islamic Boarding School in Bogor is used as a haunt for the spread of radicalism by some people

\subsection{Campus}

The spread of radical ideas on public college campuses is more effective than religious colleges. Individuals with a strong background in Islamic scientific traditions are less likely to join radical movements, and unfortunately this condition is not so much found in general higher education. As a result, exclusive religious understanding thrives on public college campuses.

The efforts of radical groups to attract student groups can also be seen by circulating among students internally that there are pesantren that recruit individuals to go to the Middle East and join ISIS (Personal Interview Student of Chemical Analyst Academy, 2017). In fact, it is not uncommon to find leaflets that tend to be radical among students (personal interview, 2017). The existence of HTI in Bogor is one of the penetration of radical ideas on campus campuses in the Bogor area. The 2016 Khilafah Declaration on the IPB campus is a form of penetration on campus life.

Reluctance to declare an attitude that is clearly contrary to national and Indonesian values, is the cause of the growing opposition to the Pancasila among students. Efforts to reduce radicalism among campus communities have indeed been carried out by various elements of the campus in Bogor, both campus bureaucracy, students and universities. However, there has not yet been any synergy between elements in the intra-campus and with other universities in Bogor.

\subsection{Urban society faces radicalism}

The phenomenon, symptoms, and expression of contemporary religious religiousity in urban society in Indonesia is very complex, both in terms of the emergence and development of theology, doctrine and religious rituals as well as in relation to other areas of life. Changes and developments so fast in urban life lead to disruption, disorientation and dislocation of urban communities. In such circumstances, there are more and more urban residents trying to find 'meanings', to find solace, or even escapism in religion, religiosity or spiritualism (Azrumardi Azra). See Azyumardi Azra (2017), Urban Community Relief (1), Jakarta, Republika.co.id on the page: http://republika.co.id/berita/kolom/resonansi/17/07/12/oszdgc319-relijiusitas- urban1 community.

Radicalism actually often develops in urban areas or among the relatively well-established. Ideology, extreme narratives and threatening imagination (siege mentality) attracts the interest of some economically established groups in radicalism. Increasing religious spirituality is sometimes not accompanied by the social spirit of the community. This happens because there is a new mindset that considers, "fix yourself first, socialize later". However, there was a miss during the search for meaning in this religion. Mistakes when looking for a teacher or wrong when attending religious studies lead to fatal things. This also happened to ex-terrorism in Bogor. The unrest of the radicalists was finally shed in acts of terror in various regions in Indonesia.

Bogor which is divided into cities and regencies, has the opportunity to become the basis of radicalism. ease of access to information, availability of adequate public transportation, enthusiastic Islamic spirit. Referring to Tilly's view related to social movement. Salafi groups in Bogor become easy to move because of the geographical factor Bogor, Bogor has the ease of all access, while Bogor District provides nature as a survival exercise. Bogor district distance with Jakarta only three hours. so that the action planned at Leuwiliang can easily be executed in Jakarta. This becomes clear because the spread of radicalism doctrine has the same core teachings, as in formulating a salafi typology formulation that has a radical tendency 
social movements that start from one mosque to another, one study of Islam into another Islamic study.

This social movement finally experienced a transformation into a radical movement when the teaching of other anti-groups strengthened. initially only discussed the general teachings of Islam, such as fiqh of worship (Fiqh Ibadah) developed into fiqh siyasah. This social movement also becomes bold because there is an identity fusion they believe in. there are friends who support group action and ideas. The bad thing is that this social movement has finally become a threat to Bogor's community disintegration

\section{Conclusion}

The city of Bogor as a Jakarta buffer city turned out to contribute to the growth and development of the radicalism movement, the article with this status Bogor residents left public activities in Bogor thus creating an empty space that was used by intolerant groups. One of the empty spaces that are successfully used was a house of worship. Contestation between Islamic community organizations has limited space available, these organizations are less able to deal with the occupation of public space, especially when houses are worshiped in housing. The spread of radical ideas has occurred systematically in Bogor. Mosques, Islamic boarding schools and campuses are three vulnerable places in the spread of intolerant and radical ideas, which in turn lead to acts of terrorism. The mosque is an effective means of capturing people with various types of social segmentation. Pesantren and campus, are educational institutions where young people become vulnerable groups of objects of radicalism.

\section{References}

[1] The Central Statistic Agency (Badan Pusat Statistik), https://www.bps.go.id/publication/2017/11/27/500b5f875d5762ffb4e7a589/statistik-transportasidarat-2016.html. Page 45. diakses 27 September 2018

[2] Badan Pusat Statistik Kota

Bogor,https://bogorkota.bps.go.id/statictable/2018/05/14/117/banyaknya-penduduk-menurut-

kelompok-umur-dan-jenis-kelamin-2016.html, accessed on 27 September 2018

[3] Badan Pusat Statistik Kab Bogor, https://bogorkab.bps.go.id/statictable/2017/05/18/9/jumlahpenduduk-kabupaten-bogor-menurut-kecamatan-.html accessed on 27 September 2018

[4] Charles Tilly," Social Movements as Historically Specific Clusters of Political Performances, "Berkeley Journal of Sociology 38 (1994): 1-30.

[5] Sejarah Kabupaten Bogor, http://bogorkab.go.id/index.php/page/detail/1/sejarah-kabupatenbogor\#.W6_d12gzY2w accessed on 18 January 2017

[6] Rucitra Deasy Fadilla, Perkembangan Tata Kota Bogor Dari Abad Ke-18 Hingga Abad Ke-20,

[7] Swann, Willlian B, Angel Gomez, D Connor Seyle, Carmen Huici, and Francisco J Morales . 2009. "Identity Fusion: The Interplay of Personal and Social Identities in Extreme Group Behavior." Journal of Personality and Social Psychology 995-1010.

[8] Skripsi Universitas Indonesia, 2012

[9] Nina Lubis Dkk, Sejarah Perkembangan Islam di Jawa Barat, Yayasan Masyarakat Sejarawan Indonesia. 2011

[10] Fitri Nurhayati, Peran Keagamaan Habib Abdullah Bin Muhsin Al Attas di Empang, Bogor, Jawa Barat, Skripsi Universitas Islam Negeri Sunan Kalijaga Jogjakarta, 2016

[11] Number of residents in Bogor according to the Believer can be seen in BPS' Report 2016

[12] Asad Said Ali, Al Qaeda:Tinjuan Sosial Politik, Ideologi dan Sepak Terjangnya, Jakarta: LP3ES,

2014 
[13] Main Report, Lepas Kendali Hilang Orientasi, Majalah Gatra,http://arsip.gatra.com/2009-0723/majalah/artikel.php?pil=23\&id=128662, accessed on 5 June 2017

[14] Muh. Taufiqurrahman, Indonesia, Journal of The International Centre for Political Violence and Terrorism Research, Volume 7, Issue 11, December 2015-Januari 2016

[15] Noorhaidi Hasan, Laskar Jihad: Islam, Militancy and The Quest of Identity In Post New Order Suharto

[16] Interview with ex-prison of Military Training Case of Juntho Aceh, 19 May 2017

[17] Hasani Dkk, Wajah Para Pembela Islam, Jakarta: Pustaka Masyarakat Setara, 2011

[18] Elizabeth Fuller Collins, "Islam is the Solution" Dakwah and Democracy in Indonesia, Paper June 2004

[19] Suhanah, Jaringan Salafi Bogor, Jurnal Harmoni Oktober-Desember 2010

[20] House of Commons Home Affairs Committee 'Roots of violent radicalization" Nineteenth Report ofSession 2010-12 https://publications.parliament.uk/pa/cm201012/cmselect/cmhaff/1446/1446.pdf diakses pada 18 Januari 2017

[21] Quintan Wiktorowicz, Radical Islam Rising: Muslim Extremism in the West, Oxford: Rowman \& Little eld, 2005

[22] Arun Kundari, A Decade Lost: Rethinking Radicalization and Extremism, Claystone United Kingdom, 2015

[23] SMRC, NKRI dan ISIS: Penilaian Massa Publik Nasional, Survei SMRC Juni 2017

[24] Setara Institute, The Survey Report about State Senior High School Students' Perception ofJakarta and Bandung Raya Against the Tolerance 2016, Jakarta: Setara Institute, 2016

[25] Setara Institute,The Survey Report about State Senior High School Students' Perception ofJakarta and Bandung Against the Tolerance, Jakarta: Setara Institute, 2015

[26] Parlemen Uni Eropa, The Involment of Salafism/Wahabism in The Suport and Supply of Arms toRebel Groups Around The World, Brussel: European Union, 2013

[27] Tuncay Kardas, Omer Behram Ozdemir, Avrupalı Yabancı Savaşcılar: Kimlik, Sosyal Medya veRadikaleşme, Istanbul: Seta Foundation, 2015

[28] John A. Turner, Religious Ideology and the Roots of the Global Jihad: Salafi Jihadism andInternational Order, New York: Palgrave Macmillan, 2014

[29] Frazer Egerton, Jihad in The West: The Rise of Militan Salafism, New York: Cambridge University Press, 2011

[30] Henri Lauziere, The Making of Salafism: Islamic Reform in the Twentieth Century, New York: Columbia University Press, 2016

[31] Interview with the residents in Indraprasta Residence, 26 May 2017

[32] http://kotabogor.go.id/uploads/images/Transparansi\%20Publik/2017/LampiranPerwali/929-

969-KantorKesbang.pdf diakses 9 Juni 2017.

[33] Wawancara Kepala Kesbangpol Kota Bogor, 10 January 2017

[34] House of Worship in West Java https://jabar.kemenag.go.id/artikel-27382- diakses tanggal 28 Juli 2017

[35] BPS (Central Statistic Agency) of Bogor Regency, Kabupaten Bogor Dalam Angka, Bogor: BPS Kabupaten Bogor, 2016 page. 103

[36] Direktorat Jenderal Bimas Islam, Tipologi Masjid, Jakarta: Religion Ministry, 2008

[37] Interview with a resident in a settlement, 26 May 2017

[38] Personal interview with ex-terrorist of Terror Case in Mapolres Cirebon, 22 Mei 2017

[39] Berkas 2 Tersangka Bom Gereja Samarinda Siap Dilimpahkan http://www.beritasatu.com/hukum/402111-berkas-2-tersangka-bom-gereja-samarinda-siap dilimpahkan.html diakses 9 Juni 2017

[40] Personal interview with a Politechnic Student of Chemical Analyst Academy, Bogor, 12 September 2017.

[41] Personal interview with a student, the member of Student Executive Board in one of private university in Bogor., 10 September 2017

[42] https://forlap.ristekdikti.go.id/perguruantinggi/search diakses pada 18 Oktober 2017 